\title{
Political Institutions and Justice Institutes Established by Congress of Lushnjë
}

\author{
Eldi Sherifi \\ PhD Candidate, Tirana Business University \\ Email: eldi-sherifi@hotmail.com
}

\section{Doi:10.5901/ajis.2016.v5n3s1p519}

\begin{abstract}
State political institutions are established by the decisions of Constituent Assemblies, but also based on legal norms with constitutional force. Is Congress of Lushnjë legitimated for the reestablishment of institutions in Albania and on which legal and constitutional norms and rules it established them? Did we have an institutional tradition? National Assembly of Vlorë declared Albania separately, but it could not create a state with political and legal institutions, neither was internationally known. Albania gained its status from the Great Powers on July 29, 1913. International Commission of Control prepared Albania's Organic Statute on April 10, 1914, which is also the first constitution of Albania's Principality. This document with legal and constitutional values was not repealed. According to the chronological criteria of the constitutional right "Lex posterior derogate priori", the Organic Statute was in force and could be serving on the creation of new political institutions. But it was not used by the Congress of Lushnjë because after the First World War, many historical events had occurred and many political circumstances had changed. The International Institution which gave Albania the status did not exist anymore. Great Forces did not exist anymore; moreover, some of those states had made a pact for its crush. The assembly's delegates unanimously created a package with six legal norms named "Fundamentals of the Kanun of the High Council" known as the Statute of Lushnjë, used as legal norms of constitutional power to fix the relations between powers which had been created through political compromise. On December 22, 1922, pursuant to Article 45 of the "Internal Regulation" the Assembly found the remedy to make legal changes and approve the "Extended Statute of Lushnjë", which had legal norms with constitutional power to fix the relations among the state's powers.
\end{abstract}

Keywords: Extended Statute, National Council, High Council, National Assembly

\section{Constitutional and Institutional Albanian Traditions, from the Independence to Congress of Lushnjë}

State political institutions are established based on the decisions of Constituent Assemblies, on legal norms with constitutional force.

Constituent Assemblies have the right to approve also the legal constitutional norms on which function the political institutions of the state. On which legal, constitutional norms was the Congress of Lushnje developed? Was it on the formal sources/acts of constitutional rights or material sources/facts?

On November 28, 1912 Albania was declared separated from the Ottoman Empire, but did not establish the state's institutions on legal constitutional norms. National Assembly of Vlora elected a provisional government but Albania didn't have a head of state and legislative power. There was not found an agreement/consensus to elect a Constituent Assembly in order to define the form of the political regime and to establish legitimate institutions, because of the extremely hard historical circumstances and the politicians' stubbornness.

Mithat Frashëri, one of the ministers of the Provisional Government of Vlora, who resigned in March 1913, wrote an article at "Dielli" newspaper, of Vatra Pan Federation, on September 16, 1915.The major shortage of Albanians according to him was the lack of unity and the inability to cooperate stimulated form jealousy and selfishness. His idea was also enforced by the thought of the German researcher Fallmerayer, who after the formation of states with Christian population in the Balkans, concluded that "the Albanians have not felt the need of the creation of compact national unity and have not accepted the thought of a chairman of their blood."(Beqir Meta, Tirana: Vatra Pan federation, Globus 2002,pg 131)

Ismail Qemali was conscious for the constitutional and institutional deficiencies of Assembly of Vlora, for this reason he asked the Prefects on December 4, 1912, that "until the establishment of the National Council by elections, the 
previous laws, regulations and formalities of the empire would be in force.".

National Assembly of Vlora, under the historical circumstances that was developed and based on the analysis of historical and political factors, may had also elected and the head of state.

The head of a state could not be elected without the authorization of the Great Powers, if this thesis is accepted, logically must be accepted that the Independence of Albania and the creation of the Provisional Government were allowed with their "authorization".

This is not true, because the Great Powers did not recognize the Declaration of Independence and the government elected from the National Assembly. Their decision was an expression of arrogance and denial of the internal right of state to express national sovereignty from the legitimate Assembly.

On December 17, 1912 Conference of the Ambassadors in London, put the discussion for Albania in the first place at their agenda, but the main purpose of some ambassadors was not recognition of Albania, but the interests of Serbia, guaranteeing a port at the Adriatic Sea.

At this Conference the ambassador of Austro -Hungary, Mensdorff/Albert von Mensdorff, proposed autonomy for Albania, but the ambassador of Russia, Alexander Von Benckendorff, asked for an autonomous state under the sovereignty of the Sultan. At the first press on December 20, 1912 sir Edward Grey stated that: "the ambassadors declared to their governments that they accepted the autonomy of Albania, under the sovereignty of the Sultan. ${ }^{2}$

The first Institution established by National Assembly of Vlora was the Leadership of the Assembly, with Ismail Qemali the leader.

The proposal was made by Rexhep Mitrovica and was unanimously accepted. After its constitution, the leadership of the Provisional Government was founded with President Ismail Qemali, and vice-President Dom Nikollë Kaçorrin, proposed form Veli Harçi. ${ }^{3}$

Their election was made through the cooperation of important political operators with transparent procedures. Discussions were created because of the lack of legal norms for the authority that would propose the name of the ministers and also the institution which could dismiss them. After the discussion was decided that the election of the ministers would be left on the decision of the president of the government .(L. Nosi, Historical Documents, pg 181).

Ismail Qemali presented a list with the ministers' names and explained that they were elected according to the contributions criteria, the recognition that they should have in Albania and abroad, and to satisfy the interests of the Ottoman Empire and Europe. The proposed ministers were: Mehmet Pashë Tetova, Myfit bej Libohova, Aziz Pashë Vrioni, Vehbi Dibra, Abdi bej Toptani, dhe Mid'hat Frashëri (L. Nosi, Historical Documents,pg 180).

The candidates for Ministers were only muslims, because there was not any representative of Orthodox or Catholic religion. With this proposal the diplomat Ismail Kamal did not act in a diplomatic way.Babë Dudë Karbunara, Pandeli Cale, Dhimitër Berati and Qemal bej Elbasani,declared themselves to be against this proposal.

Debates on the composition of the government had been very harsh and the list of ministers proposed by the president of the government was not voted. Ismail Qemali unsatisfied by the situation and in order to find a consensus for the approval of the government, the fifth day of the Assembly asked the delegates compromise for a new procedure, giving up the legitimate right of the ministerial proposal.The right was willingly passed to the National Assembly.The Parliament went into the selection procedure of Ministers by an "Albanian model" unknown from the political doctrine and judicial institutions of the state of justice.Seventeen candidates competed for the post of minister. There is no information on the person who proposed the canditates for the post of ministers.After debates it was decided that ministers would be considered the candidates that would receive an absolute majority of votes.

The election procedure was democratic .Voting was done secretely.At the begginning of the election the secretary guided from Luigj Gurakuqi, declared that at the assambley were 63 delegates.At the elections participated 57 delegates.Minister would be elected the candidate with 29 votes. The voting process lasted more with this procedure. In the first ballot won the minister mandate, Luigj Gurakuqi with 54 votes, Myfit bej Libohova with 52 votes, Mehmet Pashë Tetova with 42 votes, Mid'hat bej Frashëri with 35 votes and Abdi bej Toptani with 32 votes. To choose three ministers with absolute majority, the elections were repeated with 12 candidates who won less than 29 votes .Finally , the ministers elected from the Assambley were Luigj Kurakuqi with 54 votes, Myfit bej Libohova with 52, Mehmet Pashë Tetova with 42

\footnotetext{
${ }^{1}$ AQSH,Page 245, Ismail Qemali ,documentary ,page 28.

2 British documents for the Albanian case at the Conferrence of Ambassadors in London, F.54893/42842/12/44, nr.96, D. no. 109, Sir Eduard Grey for Sir F Cartwright-in, Foreign Office, 20 December 1912, p. 172-173.

${ }^{3}$ HHSt.A.PA. in AlH ,Vj, 22-8-859, confidential report of Lejhanec, for the foreign Ministry of Austro-Hungary, Vlorë, on 29.11.1912.
} 
votes, Petro Poga with 40 votes, Pandeli Cale with 39 votes, Lef Nosi with 37, Mid'hat Frashëri with 35 and Abdi bej Toptani with 32 votes.After the second elections the mandate of minister was assured by Petro Poga with 40 votes, Pandeli Cale with 39, Lef Nosi with 37, Mid'hat Frashëri with 35 votes, and Abdi bej Toptani with 32 votes. (L. Nosi, Historical Documents, pg.183-184).

On July 29, 1913 with the final decision of the Great Powers was determined the form of government of Albania, Autonomous Independent Principality. (A. Luarasi, Legal Acts of History of the State of Justice, second part, Tirana: Luarasi 1999, pg. 30). Pursuant to Article 6 of the Final Decision of Conference of Ambassadors in London, the draft statute should be completed within January 1914.KNK,had not finished the statute ,therefore Prince William of Wied ,started the activities of the state without legal constitutional norms. At this time in Albania,there was not a central legitimated institution for the functions of the state. Pursuant to articles 4,6,7 and 8 of the Decision of Conference of Ambassadors in London, the functions of the institutions of the Albanian Principality would be performed by KNK. (A. Luarasi, Legal Acts of the History of the State of Justice, second part, Tirana: Luarasi 1999, pg. 30).

The first act of Prince William, was the decree of the Government's President. The decree did not refer to any rule of constitutional or procedural character.The Organic Statute of Albania envisioned as a form of governance the Constitutional Principallity, with a represantative authority the Constitutional Assembly.Prince William by decree appointed the government's chairman, in conditions when other institutions lacked the Principality, exercised powers of an Absolute Monarchy. The articles of the Organic Statute of Albania reflected "small politics" of the Great Powers, against Albania.The Organic Statute of Albania ended on April 15, 1914 in Vlora.It was signed by the members of KNK, scholar Klar of Austro-Hungary,who had replaced on March 10,1914 Petroviçin,Krawefski of France,Nadolny of Germany ,Petrajev of Russia ,Harry Lamb of England and Meh'di Frashëri.The Statute had 17 chapters and 216 articels. ${ }^{4}$

Pursuant to article 8,of the second chapter ,called Sovereignty,the Prince should earn the right to exercise the powers after the oath at the National Assembly.But the National Assembly was never created. Therefore, the activity of Prince William and the institutions that were created after the adoption of the Organic Statute of Albania had been in conditions of illegality. The Organic Statute of Albania, was not applied for reshaping the government. Pursuant to Article 73, the Council of Ministers shall consist of the Prime Minister and by four ministries. The Prince decreed the government with 8 ministries.( Aleks Luarasi,Legal Acts of History of the State of Justice, second part, Tirana: Luarasi 1999, pg.40).

On September 1914,Prince William left Albania.The Organic Statute of Albania was not abrogated,and according to the chronological criteria of constitutional right "Lex posterior derogate priori" it was in force, but was not used by Congress of Lushnja for establishing new institutions, because it was not implemented from the Congres of Durrës.

Delegates of Congress of Lushnja developed their work on January 29 at 9 am with the following agenda:

1. Discussions on the measures to be taken against the decision of three Great Powers for the partition of Albania according to London Charter in 1920.

2. Discussions on the government's choice of external and internal political views according to the program of the National Meeting of Lushnjes .

3. Temporarily regime of Albania.

4. A discussion of trust or distrust of the National meeting for the provisional government.

5. The elections of the authorities according to the decision that would be taken. ${ }^{5}$

The assembly approved the second article which defines the government's attitude in internal and external point of views, after the election of the Commission was approved that :I. the government has acted out of the right and program that was given to it by the Congress of Durrësi; II. The Government has prevented the meeting of the assembly decided from the Congress of Durrës; III. Anarchy has been caused in Albania due to a bad administration. IV. Albania was led to a difficult political situation relying on specific policies. V. Using different intrigues tried to prevent the National meeting which its purpose was to save Albania from dangerous threats. From these and other antinationalist acts was decided the government's scrapping with 45 votes pro and 6 votes against, which asked to call the government for explanations". ${ }^{6}$ The assembly started the discussion for the regime that would temporarily Albania have. After many discussions was decided that except the Cabinet of the National Council/ Senate,to be established and a High Council with four members.A Commission of ten members was elected for the details of the Kannun. ${ }^{7}$ The material/facts sources and the

\footnotetext{
4. British documents V.II, doc.2, attached to Nr.54, pg. 347-366; Project the Organic Statute of Albania.

5. Documents and historical materials from the war of the Albanian population for freedom and democracy 1917-1941

6. Historical Documents and Materials from the war of the albanias for freedom and democracy1917-1941", pg.21-23

7. Circulars of the Min. of Internal Affairs of 1920, Shkodër: Nikaj, 1921, pg. 4-5
} 
formal /acts sources served as a source of right in Congress of Lushnjë, by combining the principles of our historical tradition expressed nicely from Sami Frashëri at his paper: "Shqipëria çka qenë,ç'është dhe ç'do të behet", with a modern political philosophy of Kelzeni constitutional right.

The formula of the creation of the "High Council "was found, according to our historical tradition ,consisted of four members, representatives of four religions. Sami Frashëri though the Head of the State as an elderly authority with representatives of 15 administrative units. According to him Albania should have a Republican regime with a collective head of state in charge. The Organic Statute of Albania was respected from the state of justice , which defined monarchy as regime, legitimated the continuity of institutions pursuant to article 29 , on July 1913 and the Organic Statute on April 10,1914. The legal norms which were approved were nominated as "The Basics of the Kannun of the High Council", there were six paragraphs that affirmed the basic constitutional principles of Albania. (A. Anastasi, Political Institutions and the Constitutional Right in Albania 1912-1939, Tirana: Luarasi 1998, pg.40).

The norms were: 1.The High Council must approve every project that would be presented from the Cabinet verified from the Senate; 2.has the right in a time of ministry crisis to elect a Prime Minister for the creation of a new Cabinet which would come into force when It would be approved from the Senate ; 3 .If the election of the Head of the Cabinet ,would be refused from the Senate three times in a row ,the High Council had to terminate the meting.4.The High Council doesn't have the right to distribute the Cabinet even though if there are objections between them, the general national meeting refutes the council or distributes the Senate.5.If one of the members of the High Council resigns, the other three continue their duties, if two of them resign ,two others will be elected from the Senate.6. If the King comes in the highest throne the monarchy is considered overthrown. ${ }^{8}$

The High Council was the collegial head of state and its highest representative with the executive power belonging to it,applied by the government. Its powers were summarized in two points during the discussions of the Congress: Firstly, for the announcement of Laws and secondly the creation of the new government. (G. Hysi, Organization of Albania and the political war on 1920-1924, pg. 10-13) Regency was the legal position for the temporarily realization, of the powers of the head of state at the monarchial form of government. (Gramoz Hysi, Organization of Albania and the political war on 1920-1924,pg.38).With the proposal of the delegate from Berat ,Mr.lljaz Baj Vrioni,at the High Concil were elected: Emzot Bumçi, Aqif Pashë Elbasani, Abdi Bej Toptani and Dr. Turtulli, from them, Emzot Bumçi and Dr. Turtulli would continue their mission in Paris. ${ }^{9}$

The Cabinet was the second established institution.Bektash Cakrani ,the delegate of Mallakastër,proposed for the Cabinet Sulejman Delvinën, lliaz Vrionin, Ahmet Zogun, Sotir Pecin, Ndoc Çobën e Mehmet Konicën . ${ }^{10}$ The election of the temporarily Cabinet with the head of it Sulejman Bej of Delvina and deputy Mr. Eshref bej Frashërin until Mr Sulejman Beu returned from Paris.The Minister of the Internal Affairs ,Mr. Ahmed bej Mati .Minister of Foreign Affairs Mr. Mehmed bej Konitza.Financial Minister Mr. Ndoc Çoba with deputy Mr. Idhomen Kosturi,Minister of Justice Mr. Hoxha Kadri with deputy Mr. Hysejn bej Vrioni,Minister of Education, Mr. Sotir Peci.Two General Directorates were created :the one of Public Affairs with Mr. Eshref bej Frashëri,and the one of the The Post and Telegraph with Mr.Idhomen Kosturi in charge. ${ }^{11}$ The Senate was another established institution .It was not a second room ,but a genuine monocameral Parliament/with one room,which functioned as a representative authority of the Parliament.The delegates decided the senate to have a parliamentary form called National Council,consisted of 37 members elected by the Congress, with the criteria of a representative for 20.000 residents. ${ }^{12}$ On January 31,the Ministry of Internal Affairs announced to the Prefectures „A congress was held in Lushnjë,with representatives from all areas of Albania ,except Shkodra,Lezhe,Kruje ,delegates elected from people of their districts,couldn't agree with the discussions. To notify people as soon as possible and to bring copies of the declaration to the villages.$^{13}$

\section{Albania as a Monarchy or a Republic?}

The form the state was a matter of political and legal constitutional importance. The delegates of the Congress were led by the idea of the continuity of the Albanian state according to the decisions of the Conference in London, which defined

\footnotetext{
8. AQSH, Fund.152,of.1920, file 9, pg. 3-4. First opening of the National Meeting, 21-1-1920.

9. Circulars of the Min. of Internal Affairs of 1920, Shkodër: Nikaj, 1921, pg. 3.

10. AQSH, Fund.152, of .1920, file .9, pg. 3-4. First opening of the National Meeting 21-I-1920

11. Circulars of the Min. of Internal Affairs of 1920, Shkodër: Nikaj, 1921 pg 9-10

12. also there

13. Circulars of the Min. of Internal Affairs of 1920, Shkodër: Nikaj, 1921 pg 9-10.
} 
the statute of Albania.

Recognition of monarchy, as a temporary form of governance, presented the case of exercising the duties of the Head of State, in this form of governance at the Congress of Lushnjë. The Congress wanted to remain within the international legal frame for the recognition of monarchy and for the appointment of the Head of State, trying in this way its decision to be based as much as possible on the law. (Gramoz Hysi, Organization of Albania and the political war in 1920-1924, pg. 35).

The maintain of monarchy by the Congress of Lushnjë must be treated in two aspects.Firstly,in the internal plan,was related to the compromise between the feudal lords and the bourgeoisie of that time.The compromise emerges as a concession of the new emerging class, of bourgeoisie to the old society, of feudal lords; Secondly in the external plan,which achieved the greatest importance,the maintain of monarchy was related to the critical situation of Albania at that time.The Congress tried not to violate the international decisions for Albania,like the decision of the Ambassadors Conference on July 29,1913 and later the Organic Statute of Albania,drafted from the International Commision of Control on April 10,1914. The decisions were signed also from the winning powers of Antanta.In this case Congress of Lushnje wanted to emphasize the existence of the Albanian state and the recognition that had received from the international decisions. (Gramoz Hysi Organization of Albania and the political war during 1920-1924, pg. 33-34).

The Basics of the Kannun or the Statute of Lushnje represents one of the most important constitutional acts in the history of the Albanian state and its echo was present throughout the period of years 1920-1924. Regarding the time of action, the constitutional document was temporar,as said at the discussions of the delegates until the final approval of the constitution by a Constitutional Assembly,the congress determined its meeting as the end of the Albanian case at the Peace Conference.There was created a controversy between de jure form of the Albanian state and the form of governance implemented in practice, in the years 1920-1924.

This happened because it was applied a republican form of governance, an original form with a collegiate head of state in charge. (Sali Hidri, the High Council and the form of the regime of the Albanian State in 1922-24ll At the: "Democratic and revolutionary issues of Albania during 1921-1924", Institute of History, 1977, pg. 77).

The High Council, was mostly approached with the head of state in republican form of governance, due to its features and addiction to a large extend of the National Council. (Gramoz Hysi Organization of Albania and the political war during 1920-1924,pg 61-63).

The Congress, with the creation of the new government headed by Sulejman Delvina, the High Council of State and the election of National Council, achieved the constitutionality and legitimacy of the Albanian state, as a sovereign, with institutions established by the Albanians. (A. Anastasi, Political Institutions and Constitutional Right, pg. 40).

The establishment of the High Council was a solution of „sui generis". What was the High Council a "Collective Monarchy", or a "Collective Presidency"?

At the Fundamentals of the Kannun of the High Council it was stated that "With the arrival of the king on the throne, the High Council would be surrendered", so the High Council was the regency who exercised the rights of the King.The Council of the Regency, composed of four members ,would be the head of the Albanian state, until the form of the regime would be defined by a Constitutional Assambly. How was the administration of the High Council organised? Based on the documents of the Central State Archive it appears that in its composition was a legal advisor a chief secretary who spoke foreign languages, two secretaries and a recorder. ${ }^{14}$

The High Council created many interpretations. The High Council was the collective head of the republic, for some senators / deputies. Noli referred to the High Council as our beautiful Republic. Vërlaci called it our Monarchy. Uncertainty continued at the discussions of the National Assembly on January 1922. Seifi Vllamasi at his book titled "Political Confrontations" states that members of the National Union agreed to the creation of a collegial republic, as it was decided by the Congress of Lushnjë. The Democratic Group of Gjirokastra called it Collegial Republic, having in its fundamentals the High Council. "(S. Vllamasi, Political Confrontations in Albania1897-1942, Tirana: Neriada, 2000, pg. 286).

The uncertainty was resolved by the extended statute of Lushnjë. Article 45 of the Regulation of National Council served as a legal norm to approve the extended statute of Lushnje. It sanctioned that the National Council with a majority of two thirds of the number of its members may approve the extension or the improvement of the Statute of Lushnjë. (A. Mema, https://drive.google.com/, PhD Thesis, pg.37).

14. AQSH, Fund. 146, year 1921, file. 63, pg.16-17. A letter sent from the High Council to the Prime Minister on 25.10.1920 to the High Council and its employees. 
The definite form of the regime could not be defined with the extended Statute of Lushnje. According to the decree of the Congress of Lushnjë, the form of the governance would be definied only by a Constitutional Assambley established by free democratic elections.

The elections for the Constitutional Assambley were held on December 1923, the time when Ahmet Zogu was the Prime Minister. There were not discussions about the form of the regime when the Assambley started its exercise in 1924. The debate was concentrated more on the legimitate of the elections and the powers of the High Council rather than on the form of the regime. Albania was declared Republic and Ahmet Zogu its President on January 21, 1925.

\section{References}

Beqir Meta, Tirana: Panfederata Vatra, Globus 2002 ;

AQSH, pg. 245, f.1, f. 25; Ismail Qemali documentary..., pg.28;

Lef Nosi, Historical Documents, pg.180;

L. Nosi, Historial Documents, pg. 181;

British documents for the albanian issue in the Ambasadors Conference in London.., pg.54893/42842/12/44, nr.96, D. nr.109, Sir Eduard Grey for Sir F.Cartwright-in, Foreign Office, December 20, 1912, pg. 172-173;

HHSt.A.PA.në AlH,Vj, 22-8-859, confidential report of Lejhanec, for the foreign ministry of A-H, Vlorë, on. 29.11.1912;

L. Nosi, Historical Documents pg.183-184;

A. Luarasi, Legal acts of the History of the State of Justice, second part, Tirana: Luarasi 1999, pg.30;

A. Luarasi, Legal acts of the History of the State of Justice, second part , Tirana: Luarasi 1999, fq.30;

Aleks Luarasi, Political Institutions and the Constitutional Right in Albania 1912-1939, second part, Tirana: Luarasi 1999, pg.40;

Historical Documents and Materials from the war of the albanias for freedom and democracy1917-1941 pg 21-23

British documents., V.II, doc.2, attached with Nr.54, pg.347-366; the project of the Organic statute of Albania;

A. Anastasi, Political Institutions and Constitutional Right 1912-1939, Tirana: Luarasi 1998, pg.40;

G. Hysi, Organization of Albania and the political war during 1920-1924 pg. 10-13;

Gramoz Hysi, Organization of Albania and the political war during 1920-1924, pg. 38;

Circulars of the Min. of Internal Affairs of 1920, Shkodër: Nikaj, 1921 pg. 4/5;

AQSH, Fund.152, year.1920, file.9, pg. 3-4. , First opening of the National Meeting 21-I-1920;

Gramoz Hysi, Organization of Albania and the political war during 1920-1924 pg. 35;

Circulars of the Min. of Internal Affairs of 1920, Shkodër: Nikaj, 1921 pg. 3;

AQSH, Fund 152, year.1920, file.9, pg. 3-4. , First opening of the National Meeting 21-1-1920;

Circulars of the Min. of Internal Affairs of 1920, Shkodër: Nikaj, 1921 pg 9-10.

Gramoz Hysi, Organization of Albania and the political war during 1920-1924 pg. 33-34;

Sali Hidri, The High Council and the form of the regime of Albania during 1922-24, at the: "Democratic and revolutionary issues of Albania during 1921-1924", Institute of History, 1977, pg. 77)

G. Hysi, Organization of Albania and the political war during 1920-1924 , pg. 61-63. 


\title{
The Role of Hospital Funding in Albania: A Situational Analysis
}

\author{
Rudina Degjoni \\ The Compulsory of Health Care Insurance Fund of Albania \\ Email: r.degioni@hotmail.com
}

\section{Doi:10.5901/ajis.2016.v5n3s1p525}

\begin{abstract}
This abstract is to provide a concise description of the role of hospital funding in Albania. For many years, hospitals in Albania been funded on an historical and line-by-line basis. From year to year, the budgets has based on the previous year's funding with adjustments based on inflation and political factors. The Health Insurance Fund of Albania is preparing to take over funding decisions with respect to hospitals in January 2017, in the event they are requested to do so. This abstract proposes a fives year program in which Health Insurance Fund of Albania could begin immediately with changes to hospital funding which would generate greater equity among hospitals in terms of funding based on population served. The additional data collected will also enable the Health Insurance Fund of Albania to move toward implementation of a case mix model, which be used for funding but is recommended to be used only as a method to improve the allocation process by putting cost values to cases treated including resource intensity weights reflecting the cost of services. In brief, the current situation in Albania includes the following problems as isufficiency in health financing; the national health insurance scheme is still not consolidated; planning and budgeting are not coordinated; inefficient management of financial resources and lack of transparency and accountability. These reform proposals are ambitious and require detailed planning for their implementation. Significant efforts will be required from key players in the health sector.
\end{abstract}

Keywords: health care regulation, financing health services, funding hospitals

\section{Introduction}

In Albania, the Law no.10383, dated 24.02.2011, "On compulsory healthcare insurance in the Republic of Albania"1, as amended, according to the establishment and implementation of the compulsory health care insurance scheme in Albania. The objective of this Law is to set out not only the legal status, but also the structure, the functions and the activity of the compulsory Fund of Albania. The health care insurance fund manages the financing of health care services in the compulsory health care insurance scheme. According to this, the fund finances the packages of health care services. The health care packages includes medical check- ups, all the examinations and treatments in the public primary health care public, hospitals medical, examinations and treatments in private primary health care, hospital providers, drugs, medical products and treatments by contracted providers of health services. Compulsory Health Insurance Fund of Albania is based on the contributions of employees, employers, state and other sources for other people, as provided based on the principle of solidarity². Compulsory Health Insurance Fund, scheme intends to cover the population with hospital health care services, financed by the public and private sector. Either more, the success of the funding methodology of the Albanian hospital is to create the selected hospital health care providers register, where the public and private hospital service providers will selected by the qualities criteria. The success is also, dependent on the skills of the management team of the hospitals. These skills are what will determine if the fund will use effectively and efficiently, if the incentives built into the funding model motivation for the hospital quality. The motivation, that desired, is possible only if the people involved are skilled enough to understand the Albanian hospital funding system. For the health insurance fund of Albania is the best time to do something ${ }^{3}$, to measure the activities of the health care hospital system. Releasing, hospital resources could be used by the management to increase the level of population coverage. Some of these actions would aim to improve efficiency in the area of the Albania hospital, but at the same time would address the encouragement unshared in the health financing hospital, how services delivered on time to costumer and how the

\footnotetext{
1 Law no.10383, dated 24.02.2011, "On compulsory healthcare insurance in the Republic of Albania"1, as amended

2 Fjoralba Memia (2014) "The benefits of Compulsory Health Insurance Fund of Albania"

3 WHO (2015) "Using available resources in the most efficient and equitable way"
} 